\title{
MATRIX RECORDING OF ASSEMBLY UNIT AND ASSEMBLY SEQUENCE
}

\author{
Marcin Suszyński, Jan Żurek, Robert Cieślak
}

\begin{abstract}
Su m mary
The article is an attempt to analyse matrix recording of the graph to find on assembly sequence. There has been presented the use of matrix of graphs and assembly states to model and find the assembly sequence, there has also been done short comparison of their most essential features. It has been proved, that appropriate matrix representation of the assembly unit, which is the basis of modern computer search algorithms should enable effectively to find a rational sequence of connecting its parts. There have been discussed examples of graph representation using an assembly states matrix and a graph matrix. There have been compared their possibilities in the area of finding assembly sequence leading to shortening time, and as a result limiting its costs.
\end{abstract}

Keywords: matrix, modelling of assembly sequence

\section{Macierzowy zapis jednostki montażowej - ustalenie kolejności montażu}

$$
\text { Streszczenie }
$$

W pracy przedstawiono próbę analizy macierzowego zapisu grafu do wyznaczania kolejności montażu. Przedstawiono zastosowanie macierzy grafu i stanów montażu do modelowania i ustalania sekwencji montażu. Dokonano również krótkiego porównania najbardziej istotnych ich cech. Wykazano, że odpowiednia macierzowa reprezentacja jednostki montażowej, stanowiąca podstawę współczesnych komputerowych algorytmów przeszukiwania, powinna umożliwiać efektywne ustalenie racjonalnych kolejności łączenia jej części. Omówiono przykłady reprezentacji grafu za pomoca macierzy stanów montażu oraz macierzy grafu. Zestawiono także ich możliwości w zakresie ustalania kolejności montażu, prowadzące do skrócenia czasu i w konsekwencji ograniczające jego koszty.

Słowa kluczowe: macierz, modelowanie kolejności montażu

\section{Introduction}

Taking into account the rules of assembly, disassembly, and first of all the conditions sequence of connecting parts during the product construction is a very important task for its designers, i.e. constructor and technologists.

Address: Prof. Jan ŻUREK, Marcin SUSZYŃSKI, DSc. Eng., Poznań University of Technology, Institute of Mechanical Technology, Piotrowo 3, 60-965 Poznań, e-mails: jan.zurek@ put.poznan.pl, marcin.suszynski@put.poznan.pl, Robert CIEŚLAK, DSc. Eng., The State School of Higher Professional Education in Konin, Department of Technology, Wyszyńskiego 3c, 62-510 Konin, e-mail: robertcieslak@wp.pl 
To model the sequence of product assembly there are used mainly graphs shown in the form of matrices ensuring their simple transformation into the form useful for a computer programme. The relations between particular parts and assembly units, orientation in space, directions of connection and the rules of their determination (basing) are the most essential parameters of an assembly technological process.

One of the most popular and simple among theories of graphs is an incidence matrix, where its recording reqires $n \times m$ memory space, and the access to its information is in many cases difficult. To acquire information about existence of the specific edge connecting $\mathrm{x}$ and $\mathrm{y}$ vertices, or to which vertices lead the branches stemming from them, requires searching through all columns of the matrix.

An alternative is a presentation of the graph using the vertices neighbourhood matrix, called an adherence or connections matrix, defined as B $=\left[\mathrm{b}_{\mathrm{ij}}\right]_{\mathrm{n}} \mathrm{X}_{\mathrm{n}}$, where $\mathrm{n}=|\mathrm{X}|$.

Other representations suggested in this text and works [1-4], are state of assembly matrices and a graph matrix. Their more common use results from easiness of construction and possibility of selection of appropriate algorythms to indicate the assembly sequence.

\section{Representation of the graphs using the state matrix}

To describe directed graph, reflecting possible product assembly sequences, it is necessary, as it was metioned earlier, to have an appropriate data structure which could be a state matrix with dimensions $n \times n$ (square matrix; the number of lines equal to the number of columns), and hence it can be used for products (assembly units) with the limited number of states. Their decrease can be achieved as a result of division of a product into smaller units from which each is considered separately and the number of states for each of them will become automatically smaller.

Matrix is completed with numerical values $x_{i j}>0 \cup x_{i j}<0$, if two vertices are connected with the edge (record of connections informs about the possibility to add a part to a given state of assembly), and zero (or lack of value) in case of lack of connections between them. Its construction is similar to adjacence matrix, where in the method presented in the works [1-3], the method of determining sequence of assembly is symmetrical, which allows to store much bigger number of information than in asymmetrical one, (data on one connection can be recorded both in lower and upper triangles of the matrix; storing information in one matrix triangle requires $n(n-1) / 2$ bits of memory), including those related to connected parts, i.e. a predecessor and a successor. Matrix of directed graph states of a typical assembly unit is presented in Fig. 2a. 


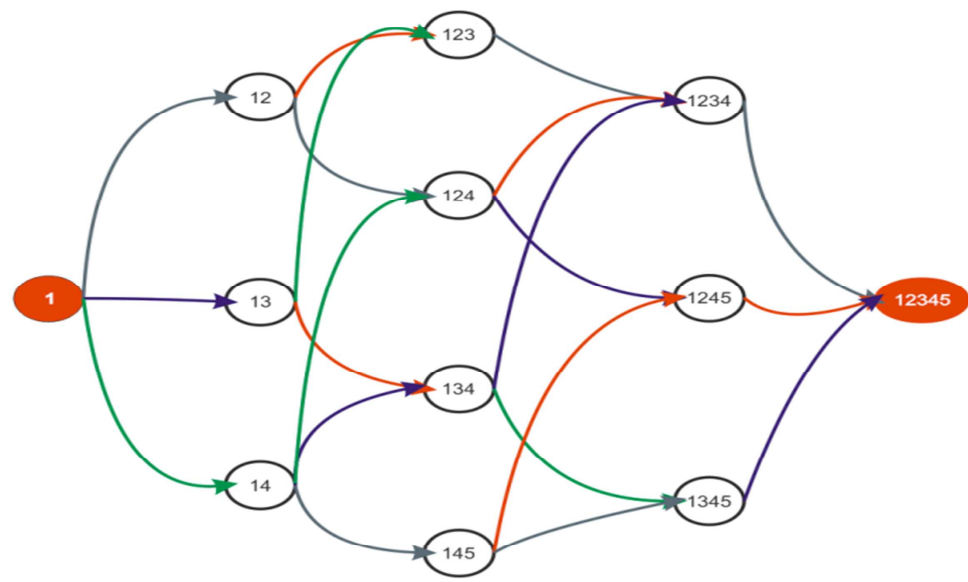

Fig. 1. Directed graph of a construction structure of a typical assembly unit

a)

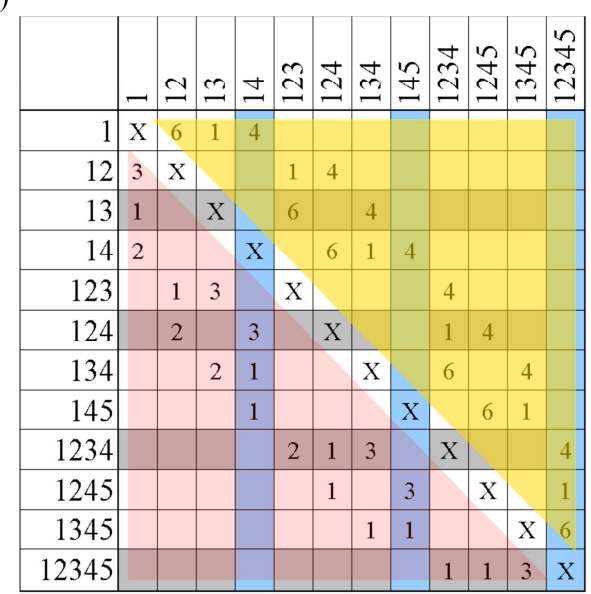

b)<smiles></smiles>

Fig. 2. Matrix of assembly states of the directed graph of the construction structure of the assembly unit from Fig. 1 (a), typical directions of adding parts (b)

Positive values in its upper triangle define existence of connection between particular assembly states $\mathrm{x}_{\mathrm{i}}$ and $\mathrm{x}_{\mathrm{j}}$, and assumed, according to Fig. $2 \mathrm{~b}$, direction of adding parts, and in lower triangle (pink colour) they represent a type of connection between parts (state of assembly and assembled part). Connections are usually marked using a numerical code which exemplary values $\mathrm{x}_{\mathrm{ij}}$ in the matrix are as followes: $\mathrm{x}_{\mathrm{ij}}=1$ for screw joint, $\mathrm{x}_{\mathrm{ij}}=2$ for packing ring, $\mathrm{x}_{\mathrm{ij}}=3$ for 
key joint. In the Fig. 3 authors presented an example of the state matrix implementation into the individual Mssasembly program.

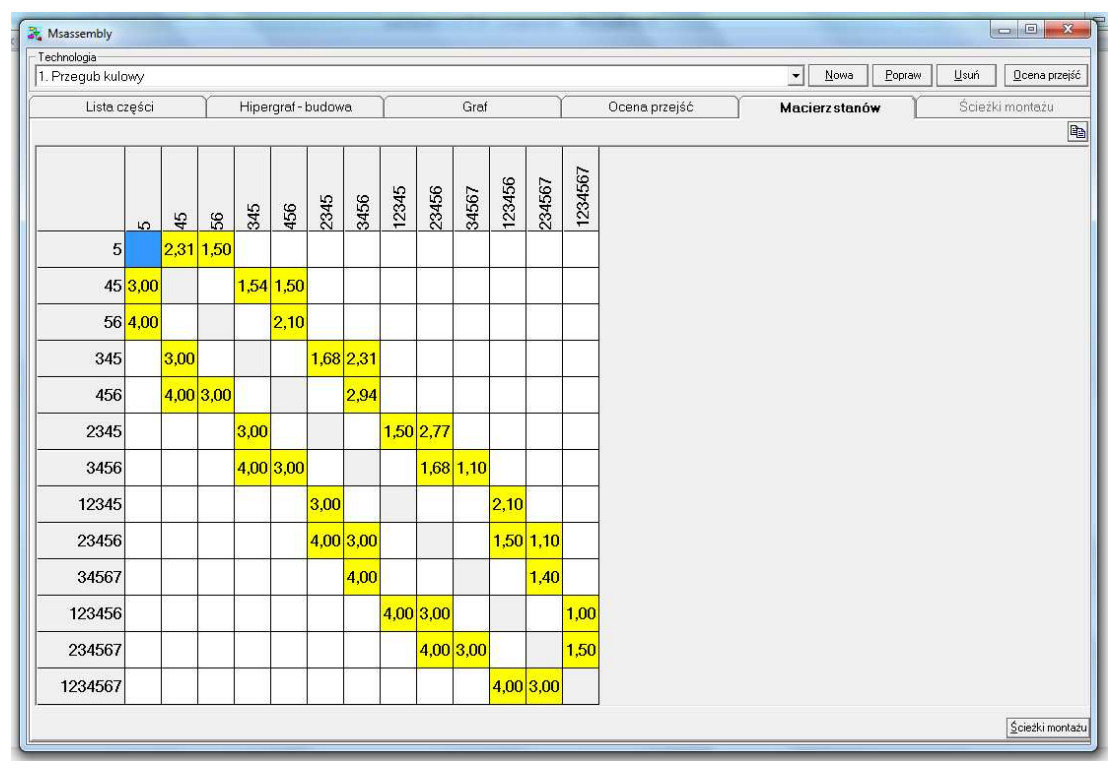

Fig. 3. View of a window of the state matrix in the Msassemly program

\section{Representation of a graph using a graph matrix}

The graph matrix $H=\left[h_{i j}\right]_{n x(n+4)}$ with dimensions $n \times(n+4)$ is a connection of square matrix of $n$ degree with four columns including information about succesors, predecessors and lack of connection between vertices in relation to the analysed line $[5,6]$. In contrast to adjacence matrix, it does include not only zeros and ones but also values of matrix $x_{i j}$ belonging to the interval $\{-(n+1)$, $3(n+1)\}$ dependent on the type of relation between described vertexes which can be both parts and particular assembly states (during determination of the assembly sequence, there are no loops, therefore we resigned from presentation of the column related to them).

Taking into account relations between particular vertices (assembly states) with square matrix we put values $\left(\mathrm{x}_{\mathrm{ij}}\right)$ from particular intervals:

$$
-(\mathrm{n}+1)<\mathrm{x}_{\mathrm{ij}} \leq 0 \Leftrightarrow\left(\mathrm{x}_{\mathrm{i}}, \mathrm{x}_{\mathrm{j}}\right) \notin \mathrm{U} \wedge\left(\mathrm{x}_{\mathrm{j}}, \mathrm{x}_{\mathrm{i}}\right) \notin \mathrm{U}
$$

-vertices $\mathrm{x}_{\mathrm{i}}, \mathrm{x}_{\mathrm{j}}$ are not directly connected,

$$
0<\mathrm{x}_{\mathrm{ij}}<(\mathrm{n}+1) \Leftrightarrow\left(\mathrm{x}_{\mathrm{i}}, \mathrm{x}_{\mathrm{j}}\right) \in \mathrm{U} \wedge\left(\mathrm{x}_{\mathrm{j}}, \mathrm{x}_{\mathrm{i}}\right) \notin \mathrm{U}
$$


-vertice $x_{j}$ is a successor of vertice $x_{i}$ (there is the directed edge from vertice $x_{i}$ to vertice $x_{j}$, ,

$$
(\mathrm{n}+1)<\mathrm{x}_{\mathrm{ij}}<2(\mathrm{n}+1) \Leftrightarrow\left(\mathrm{x}_{\mathrm{i}}, \mathrm{x}_{\mathrm{j}}\right) \notin \mathrm{U} \wedge\left(\mathrm{x}_{\mathrm{j}}, \mathrm{x}_{\mathrm{i}}\right) \in \mathrm{U}
$$

-vertice $x_{j}$ is a predecessor of vertice $x_{i}$ (there is the directed edge from vertice $x_{j}$ to vertice $x_{i}$ ),

$$
2(\mathrm{n}+1)<\mathrm{x}_{\mathrm{ij}}<3(\mathrm{n}+1) \Leftrightarrow\left(\mathrm{x}_{\mathrm{i}}, \mathrm{x}_{\mathrm{j}}\right) \in \mathrm{U} \wedge\left(\mathrm{x}_{\mathrm{j}}, \mathrm{x}_{\mathrm{i}}\right) \in \mathrm{U}
$$

-vertice $x_{j}$ is both a predecessor and a successor of $x_{i}$ (in authors' suggestions [1, $3]$ there is no such a relation).

Three additional columns of the matrix (Fig. 4) include information about the first successor $\mathrm{S}$, predecessor $\mathrm{P}$ and the lack of $\mathrm{U}$ connection. Writing definitions of vertices to graph matrix, which results from the number of parts in particular assembly units, causes assigning to them natural values from 1 to $\mathrm{n}$ (the state of assembly 14 in Fig. 4 was assigned, e.g. value 4).

In each element of matrix $\mathrm{x}_{\mathrm{ij}}$ there was coded not only the type of incidence of vertices $\mathrm{i}$ and $\mathrm{j}$, and also the indicator of another vertice being in the same incidence with $\mathrm{i}$ as $\mathrm{j}$ exists. Value in the matrix informs not only whether the edge connecting vertices $i$ and $j$, but includes additionally address of the next vertice which is in the same relation with vertice $i$ as vertice $j$. Vertice 2 (state of assembly 12) has 2 successors $S(2)=\{5,6\}$ (assembly states 123 i 124; black dashed line), 1 predecessor $\mathrm{P}(2)=\{1\}$ (state of assembly 1 , i.e. the base part from which assembly begins; blue dashed line) and 8 vertices which are not connected directly to them $\mathrm{P}(\mathrm{U})=\{3,4,7,8,9,10,11,12\}$ (green dashed line). For $\mathrm{x}_{4,14}$ (line 4, column 14) we write 5 (first successor), $\mathrm{x}_{4,6}=6$ (line 4, column 6), because the vertice is the second in sequence successor and $x_{4,7}=6$ (line 4 , column 7), the last successor; order of successors is marked in Fig. 4). The element of matrix $x_{4,15}=1$ (line 4, column 15), because the vertice is the first and the only predecessor of vertice 2 and $\mathrm{x}_{4,2}=14$ (value from interval $(\mathrm{n}+1)<\mathrm{x}_{\mathrm{ij}}<$ $<2(n+1)$, i.e. $(12+1)<12+1+1<2(12+1)$; line 4 , column 2$)$. The first not connected directly with vertice 2 is a vertice 3 , that is why $x_{4,16}=3$ (line 4 , column 16), the next not connected vertices take respective values $x_{4,4}=-4$, $\mathrm{x}_{4,5}=-7, \mathrm{x}_{4,8}=-9(\ldots)$. 


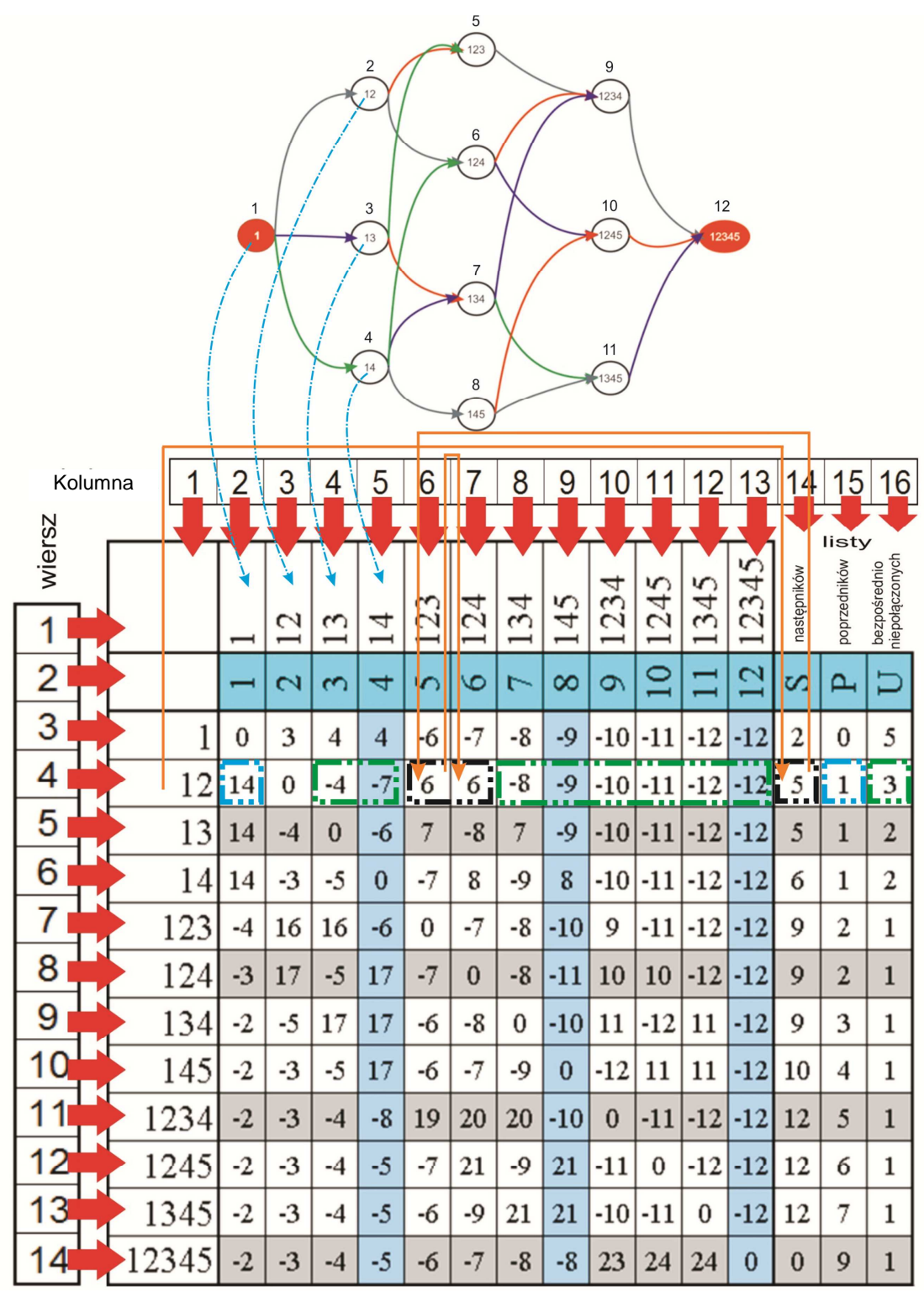

Fig. 4. Matrix of directed graph of construction structure from Fig. 1

\section{Summary}

The results of the authors' research proved, that the representation of assembly unit using the matrix, which is the basis of modern computer 
algorithms of search, should enable efficiently, in the sense of time and cost, to determine rational sequence of connecting parts of a product.

Matrices of assembly states and a graph can as well represent assembly unit or the whole product during determination the sequence of their assembly. The choice is determined mainly by the algorithm used for their search in order to find previously accepted criteria concerning, e.g. evaluation of transitions between particular assembly states. In some existing algorithms, there are used for this purpose neighbourhood and incidence matrices, e.g. due to the limited number of available information they enable only the recording of the construction structure, i.e. construction limitations of a product due to assembly. Comparison of basic possibilities of matrices concerning determination of the assembly sequence is included in Table 1 .

Table 1. Comparison of basic possibilities of the matrix related to determination of assembly sequence

\begin{tabular}{|c|c|c|c|c|}
\hline $\begin{array}{c}\text { Neighbourhood } \\
\text { matrix }\end{array}$ & $\begin{array}{c}\text { Incidence } \\
\text { matrix }\end{array}$ & $\begin{array}{c}\text { Graph } \\
\text { matrix }\end{array}$ & $\begin{array}{c}\text { Assembly states } \\
\text { matrix }\end{array}$ \\
\hline $\begin{array}{r}\text { Includes information about } \\
\text { evaluation of transitions } \\
\text { between particular states of } \\
\text { assembly or vertices }\end{array}$ & No & No & No & Yes \\
\hline $\begin{array}{r}\text { Includes directly available } \\
\text { information about } \\
\text { successors and predecessors }\end{array}$ & No & No & Yes & Yes \\
\hline $\begin{array}{c}\text { Symmetry of the matrix } \\
\text { allowing to include larger } \\
\text { number of information } \\
\text { about transition }\end{array}$ & Yes & No & No & Yes \\
\hline
\end{tabular}

Matrix of the graph in the best possible simple way presents preferred directions of transitions between particular states of assembly, i.e. from the lower to the higher along with hierarchical presentation of solutions from the best one to the worst one. However, if it was possible, as in the case of the assembly states matrix, to include information about evaluation of transitions between particular states of assembly, it needs some modification. The solution of the problem could be adding indices to particular elements $x_{i j}$ or the second matrix describing assembly unit. 


\section{References}

[1] M. SUSZYŃSKI, O. CISZAK, J. ŻUREK: Metodyka ustalania kolejności montażu z użyciem hipergrafu, grafu skierowanego i macierzy stanów. Archiwum Technologii Maszyn i Automatyzacji, 4(2009)4.

[2] M. SUSZYŃSKI, O. CISZAK, J. ŻUREK: Modelowanie montażowej struktury wyrobu za pomocą hipergrafu i grafu skierowanego oraz ustalanie dopuszczalnej kolejności montażu. Archiwum Technologii Maszyn i Automatyzacji, 4(2008)28.

[3] M. SUSZYŃSKI, J. ŻUREK: Algorytmizacja ustalania kolejności montażu za pomocą hipergrafu i grafu skierowanego. Zeszyty Naukowe Politechniki Poznańskiej, Budowa Maszyn i Zarządzanie Produkcją, Poznań 2009.

[4] J. ŻUREK, O. CISZAK: Modelling and simulation of assembly sequence of machine parts and sets. Advances in Manufacturing Science and Technology, 26(202)3.

[5] J. BŁAŻEWICZ, E. PESCH, M. STERNA: A novel representation of graph structures in web mining and data analysis. Omega, 2005.

[6] M. STERNA: Problems and algorithms in non-classical shop scheduling. Scientific Publishers OWN, Poznań 2000.

Received in December 2012 